\title{
HIPOTEZA PANPROTOPSYCHICZNEGO IDENTYZMU BERNHARDA RENSCHA *
}

\author{
Uwagi wstępne
}

Odwieczny filozoficzny problem stosunku duszy do ciała stał się dzisiaj interdyscyplinarnym problemem, szeroko dyskutowanym nie tylko przez filozofów i psychologów, lecz także przez etologów, neurologów i zoologów, czy ogólniej mówiąc, biologów. W sensie szerszym ujmuje się ten problem jako stosunek materii do ducha czy duszy do ciała, natomiast w sensie węższym jako stosunek mózgu (centralnego systemu nerwowego) do świadomości. Teoretycznie można zająć wobec tego zagadnienia trzy stanowiska: po pierwsze można powiedzieć, że jest to problem pozorny, po drugie, że jest to problem prawdziwy, lecz nierozwiązywalny i po trzecie, że jest to problem prawdziwy i rozwiązywalny. Autorzy opowiadają się najczęścciej za trzecią możliwością. Równocześnie zdają sobie sprawę z tego, że duchowa strona jest trudna do uchwycenia zarówno zwykłymi środkami przyrodniczego poznania, jak i filozoficznego myślenia ${ }^{1}$. Wszystkie poglądy na stosunek duszy do ciała oscylują między dwoma biegunami, między skrajnym dualizmem i skrajnym monizmem. Skrajny dualizm zakłada istnienie dwóch całkowicie odrębnych substancji, natomiast skrajny monizm dopuszcza istnienie tylko jednej jedynej materialnej względnie duchowej substancji. W dyskusjach nie podejmuje się problemu filozoficznego pluralizmu, zakładającego istnienie trzech substancji, mianowicie ducha, duszy i ciała.

G. Vollmer wymienia następujące odmiany dualizmu: (1) Paralelizm, według którego mózg i dusza są niezależne, jednak ich czynność jest zsynchronizowana (Wundt). Paralelizm może wystąpować także w odmianie monistycznej (Fechner). (2) Autanomizm zakładający przypadkowy stosunek duszy do ciała. Jest to odmiana wprowadzona sztucznie przez Vollmera i nie posiada żadnych przedstawicieli. (3) Okazjonalizm, według którego współdziałanie duszy i ciała jest zagwarantowane i chronione

* Bernhard Rensch, ur. w 1900 r. w Thale (Harz), z wykształcenia zoolog, boganik, chemik i filozof. W latach 1937-54 był dyrektorem Muzeum Przyrodniczego w Münster. W latach $1947-68$ był profesorem zoologii w Uniwersytecie w Münster. Pozostawił bogatą spuściznę naukową.

${ }^{1} \mathrm{~F}$. Wuketis, Zustand und Bewusstsein, Hamburg 1985, 202-203. 
przez Boga (Geulincx, Malebranche). (4) Harmonia z góry ustanowiona, według której Bóg przy stworzeniu niejako zaprogramował współdziałanie duszy i ciała (Leibniz). (5) Dualistyczny epifenomenalizm, według którego mózg steruje duchem, bez działania zwrotnego (Ayer). (6) Animizm zakładający, że duch ożywia każdą materią, a więc steruje także mózgiem (Platon, Plotyn, św. Augustyn). (7) Interakcjonizm, według którego mózg i dusza współdziałają wzajemnie (Kartezjusz, Penfield, Popper, Eccles, Ditfurth). Tego rodzaju dualizm nosi też nazwę dualizmu psychoneuronalnego ${ }^{2}$.

Odmiany psychoneuronalnego monizmu są według Vollmera następujące: (1) Monizm neutralny, według którego dusza i ciało stanowią dwa aspekty jednej jedynej substancji, zresztą nieznanej (Heraklit — logos, Spinoza - Bóg - natura, Schelling - absolut, Ostwald — energia, Russell — dane zmysłowe). (2) Spirytualizm, dla którego wszystko jest Bogiem (Berkeley, Fichte, Hegel, Whitehead). (3) Ścisły materializm, według którego wszystko jest materią, duch nie istnieje wcale (Hobbes, La Mettrie, Holbach, Moleschott, Vogt). (4) Behawioryzm, zwany inaczej materializmem eliminacyjnym, według którego duch stanowi w najlepszym przypadku tylko skrótowe, a najczęściej mylące słowo dla określonych dyspozycji zachowania się. Ze wzrostem wiedzy tego rodzaju myślowe terminy zostaną zastąpione neurofizjologicznymi wyrażeniami (Watson, Skinner, Feyerabend). (5) Mionistyczny epifenomenalizm zakładający, że duch stanowi tylko epifenomen, symptom, zjawisko towarzyszące, ale nie przyczynę neuronalnych procesów (Epikur, Lukrecjusz, E. v. Hartmann, Nietzsche, Büchner, Th. Huxley). (6) Hylemorfizm, według którego materia i duch stanowią dwie zasady substancjalne, a więc stanowią jedność, która może być rozwiązana tylko pojęciowo względnie przez śmierć (Arystoteles, św. Tomasz). (7) Teoria identyczności, według której duch stanowi funkcję mózgu i występuje na pewnym stopniu organizacji i przede wszystkim przy wytworzonym centralnym systemie nerwowym (Rensch) ${ }^{3}$.

Podobne rozróżnienia przyjmuje $\mathrm{F}$. Wuketis. Wśród dualistycznych kierunków nie wymienia tylko autonomizmu, jako nie posiadającego żadnego przedstawiciela. Natomiast do wymienionych przez Vollmera kierunków psychoneuronalnego monizmu dodaje emergentyzm, według którego duch jako funkcja mózgu stanowi nowo występujący system, który przynosi duchowe własności materii. Jako zwolennika tego rodzaju rozwiązania problemu stosunku duszy do ciała wymienia Lorenza. Według Wuketisa we wszystkich formach dualizmu i monizmu wychodzimy z założenia, że problem stosunku duszy do ciała jest w zasadzie zagadnieniem

${ }^{2}$ G. Vollmer, Evolutionäre Erkenntnistheorie und Leib-Seele-Problem, [w:] Wie entsteht der Geist?, Karlsruhe 1980, 22.

3 Tamże, 22 . 
stosunku świadomości do neuronalnych procesów w mózgu. Dlatego też uważa za bezsensowne przeciwstawianie ducha całej naturze ${ }^{4}$.

W związku z podanymi przez Vollmera i Wuketisa podziałami nasuwają się wątpliwości co do jednoznacznego zaliczenia hylemorfizmu do monistycznych kierunków. Chyba słuszniej W. Brugger nazywa teorię hylemorfizmu monodualizmem (Zweieinheit) ${ }^{5}$, ponieważ zachodzi zasadnicza różnica w zastosowaniu jej do bytów poniżej człowieka i do samego człowieka. O ile w zastosowaniu do świata materialnego hylemorfizm może być zaliczony do kierunków monistycznych, o tyle w zastosowaniu do człowieka, ze względu na substancjalną samoistność duszy ludzkiej, słuszniej może być nazwany monodualizmem.

Według J. Seiferta problem duszy i ciała, ogólnie biorąc, polega na pytaniu, jak należy rozumieć stosunki zachodzące między ciałem i świadomością. W sensie bardziej specyficznym powstaje problem, jak rozumieć jedność człowieka i łączność w nim ciała i świadomości. Wszystkie odpowiedzi na to pytanie krążą dookoła problemu istoty psychicznego z jednej i fizycznego (ciała) z drugiej strony. W zależności od odpowiedzi na to pytanie kształtują się odpowiedzi na problem stosunku duszy do ciała ${ }^{6}$. Wydaje się, że podstawowy problem dotyczy przede wszystkim jedności czlowieka jako osoby, która jest podmiotem duszy i ciała. Zasadniczym bowiem jest problem ludzkiego Ja, które posiada cielesną i duchową stronę, wypowiadającą się przez świadomość w łączności z procesami mózgowymi. Rozważanie samego stosunku świadomości do mózgu jest zawężeniem tego zagadnienia do rozważania tylko wycinka problemu.

\section{Założenia i treść hipotezy identyczności Renscha}

Identyzm jest dziś modną teorią, znajdującą uznanie wśród przyrodników i niektórych filozofów. Według Vollmera pod nazwą teorii identyczności jest rozpowszechniony umiarkowany materializm, który ujmuje duszę i świadomość jako funkcje centralnego systemu nerwowego, szczególnie mózgu ${ }^{7}$. Tego rodzaju materialistyczny monizm, pisze G. R. Taylor, został niedawno sformułowany na nowo przez grupę australijskich filozofów pod nazwą Central State Materialism ${ }^{8}$. Rozpowszechniony przez Renscha panprotopsychistyczny identyzm uważa Wuketis za najgłębszy i najbardziej szeroki system, jaki wyszedł w 20 w. spod pióra biologa

${ }^{4}$ W uketis, dz. cyt., 20-206.

5 W. Brugger, Philosophisches Wörterbuch, Freiburg 1950, 135.

${ }^{6} \mathrm{~J}$. Seifert, Das Leib-Seele-Problem in der gegenwärtigen philosophischen Diskussion, Darmstadt 1979, 120.

7 Vollmer, art. cyt., 20.

${ }^{8}$ G. R. T a y lor, Die Geburt des Geistes, Frankfurt a. Main 1985, 41. 
i przyrodnika. Wuketis dodaje, że Rensch dawał początkowo swej hipotezie nazwę ,panpsychizm”, a nazwę ,,protopanpsychizm” wprowadził później, aby odróżnić swój pogląd od teorii hylozoizmu. Różnica między panprotopsychizmem a hylozoizmem polega na tym, że według hylozoizmu wszystkie przedmioty tego świata posiadają duszę, natomiast według panpsychizmu materia posiada zdolności do wyprowadzania psychicznych, względnie duchowych własności. Panprotopsychizm przypisuje materii ukryte założenia, protopsychiczne komponenty, które w filo- i ontogenetycznym rozwoju wyprowadzają skomplikowany system nerwowy i sukcesywnie prawdziwe psychiczne zjawiska ${ }^{9}$.

Punkt wyjścia stanowi dla Renscha teoria ewolucji. Człowiek posiada swoje korzenie w naturze i pod względem anatomicznym oraz fizjologicznym różni się względnie mało od małp człekokształtnych. Dopiero dzisiejszy człowiek różni się od nich zasadniczo przez swoją mowę, duchowe zdolności i kulturę. I tu powstaje zasadnicze pytanie, jak doszło do tego szczególnego stanowiska człowieka w przyrodzie, czyli jak powstały duchowe zdolności, które różnią nas w sposób zasadniczy od materialnego świata. Do rozwiązania tego zagadnienia możemy dojść, zdaniem Renscha, wychodząc nie z przyrodniczych wyników badań, lecz z analizy naszych przeżyć, jak spostrzeżenia, wyobrażenia, uczucia, myślenie, akty woli. Tego rodzaju procesy przeżywa każdy człowiek i choć uchodzą one za coś tajemniczego, to jednak stanowią coś najbardziej realnego, gdyż stanowią niepowątpiewalne fakty. Rensch właśnie tym różni się od ścisłego materializmu, że procesy psychiczne uważa za pierwotne dane. Natomiast procesy mózgowe poznajemy w oparciu o metody indukcyjne i dedukcyjne ${ }^{10}$.

Podobne zjawiska zachodzą jednak według Renscha także u zwierząt. Wobec tego musiały one powstać gdzieś i kiedyś u wyższych i niższych zwierząt, by $w$ długim procesie ewolucji rozwinąc się $w$ duchowe zdolności dzisiejszego Homo sapiens. Chcąc jednak poznać, w jakim stopniu zjawiska psychiczne zachodzą u zwierząt, jesteśmy skazani na wnioskowanie przez analogię. Jako kryterium mogą służyć anatomiczne, histologiczne, cytologiczne i fizjologiczne podobieństwo mózgów, narządów zmysłowych, a szczególnie zdolność komórek nerwowych do wyprowadzania psychicznych zjawisk ${ }^{11}$. Dyskusje nad tym problemem prowadzą, zdaniem Renscha, do przekonania, że porusza się tu bezpośrednio problem

9 W u k etis, dz. cyt., 229.

10 B. Ren s ch, Das universale Weltbild. Evolution und Naturphilosophie, Frankfurt a. Main 1977, 256-257; Tenże: Stammesgeschichte des Lebendigen, [w:] Wie entsteht der Geist, Karlsruhe 1980, 41-43.

11 Tenże, Stammesgeschichte des Lebendigen, 42-43; Tenże: Basale Prinzipien der Evolution mit besonderer Berücksichtung der Psychogenese, [w:] Evolution, Fortschrittsglaube und Heilserwartung, Stuttgart 1970, 47. 
wszystkich materialnych bytów i określa się przez to nasz ontologiczny obraz świata ${ }^{12}$.

Dla uzasadnienia swego założenia o jedności psychicznych zjawisk u zwierząt i ludzi powołuje się Rensch na doświadczenia nad psychicznymi zdolnościami małp człekokształtnych, szczególnie szympansów. Doświadczenia te wykazują jego zdaniem, że szympanse uczą się, posiadają pamięć, ujmują związki przyczynowe, wykazują ciekawość, próbują różnych możliwości przy rozwiązywaniu zadań, używają narzędzi, modyfikują je, tworzą awerbalne pojęcia, mogą planować, logicznie rozumować, rozmawiać, nadto wykazują estetyczne uczucia, które przejawiają się w uprzywilejowaniu rytmiki i symetrii. Dalsze uzasadnienie jedności tych procesów u zwierząt i ludzi stanowią według Renscha kryteria anatomiczne, zmysłowe, mózgowe i zachowanie się zwierząt. $\mathrm{Na}$ tej podstawie Rensch wnioskuje, że można przyjąc istnienie u małp człekokształtnych duchowych czynności. Idąc jeszcze dalej, stawia wniosek, że została przekroczona duchowa przepaść między zwierzęciem i człowiekiem, co staje się jeszcze bardziej jasnym, gdy weźmiemy pod uwagę pierwszych ludzi, którzy stali na poziomie Homo erectus ${ }^{13}$. Rensch przyznaje, że duchowe życie zwierząt jest znacznie bardziej ograniczone niż u ludzi i w o wiele mniejszym stopniu odnoszone do przeszłości i przyszłości ${ }^{14}$.

Jako następny argument, który ma wskazywać na słuszność teorii identyczności, a więc na ścisłą łączność zjawisk duchowych z procesami mózgowymi, przytacza Rensch doświadczenia z gaszeniem krótkotrwałej pamięci przez elektryczny szok oraz gaszenie pamięci długotrwałej przez wstrzyknięcie puromycyny i innych chemicznych środków ${ }^{15}$. Dalszym dowodem bezpośredniego odpowiadania procesów świadomości procesom mózgowym ma być wywoływanie halucynacji słuchowych i wzrokowych przez drażnienie płatów skroniowych i wzrokowych ${ }^{16}$. Według Renscha te i tym podobne doświadczenia wskazują na to, że procesy świadomości odpowiadają każdorazowo specyficznym procesom fizjologicznym w mózgu.

Jako drugie przyjmuje Rensch założenie, że powstanie psychizmu $\mathrm{w}$ indywidualnym rozwoju człowieka przedstawia problem podobny do powstania psychizmu w ewolucyjnym rozwoju. Gdybyśmy przyjęli dualistyczny pogląd, że procesy duchowe stanowią coś niematerialnego, zupełnie i zasadniczo różnego od procesów fizjologicznych, to musielibyśmy zdaniem Renscha zapytać, jak powstały duchowe zjawiska i jak łączą się

12 Tenże, Das universale Weltbild, 221; Basale Prinzipien, 49.

${ }_{13}$ Tenże, Das universale Weltbild, 223-227; Tenże: Handgebrauch und Verständigung bei Affen und Frühmenschen, Stuttgart 1968, 112 nn.; Basale Prinzipien, $47 \mathrm{nn}$.

${ }_{14}$ Tenże, Stammesgechichte des Lebendigen, 43.

15 Tenże, Das universale Weltbild, 242.

16 Tamże, 243. 
każdorazowo $\mathrm{z}$ określonymi czynnościami naszego mózgu. Pogląd, że w każdym embrionalnym stadium rozwoju siła wyższa ,wkłada” duszę do stającego się człowieka, odpowiada może religijnym wyobrażeniom, jednakże $\mathrm{w}$ biologicznym aspekcie napotyka na nierozwiązywalne trudności. Musielibyśmy bowiem pytać, jak „dusza” (Rensch pisze to słowo w cudzysłowie) może wykazywać tu swoje cechy, skoro odziedziczyła je po rodzicach i dalszych przodkach. Trudności te wiążą się z jego założeniem, że wszystkie duchowe czynności są dziedziczne, jako złożone w wyposażeniu genowym. Przykładowo jako dziedziczne wymienia następujące cechy: muzykalność, szybkość reakcji, labilność, indywidualne tempo cielesnych i myślowych czynności, zdolności matematyczne i in. ${ }^{17}$ Gdybyśmy przyjęli, że dusza łączy się z ciałem według zasad dualizmu, to według Renscha nie potrafilibyśmy wyjaśnić, jak niezliczone wrażenia, wyobrażenia, akty myślenia i woli łączą się każdorazowo ze specyficznymi procesami w mózgu. Gdyby dualizm był słuszny, to musiałoby istnieć specjalne prawo, według którego np. wrażenie „czerwonego” byłoby przyporządkowane akreślonemu procesowi $\mathrm{w}$ mózgu ${ }^{18}$. Prawa psychiki stanowiłyby wtedy całkowicie samodzielną kategorię, której zgodność z odpowiadającymi jej fizjologicznymi procesami w mózgu byłaby niezrozumiała dla samego dualisty ${ }^{19}$.

Trzeba przyznać, że uzasadniając swą hipotezę identyczności Rensch sam zaznacza, iż musimy postawić pytanie, co obecnie wiemy o związku fizjologicznych procesów mózgowych z odpowiadającymi im zjawiskami duchowymi. Rensch przyznaje, że nasze wiadomości w tym względzie są ograniczone. Zrozumieniu tej problematyki przeszkadza wyobrażenie duszy jako pierwotnej jakości, która utożsamia się z naszym Ja. Przeciwko temu utożsamieniu przemawiają zdaniem Renscha doświadczenia z oddzielaniem półkul mózgowych przez przecięcie spoiwa wielkiego. W wyniku tego przecięcia ma powstawać, jak wierzą niektórzy autorzy, podwójne Ja w człowieku ${ }^{20}$.

Przyjmowanie przez dualistów niematerialnych psychicznych procesów u człowieka czyni według Renscha niezrozumiałym, skąd dotychczas nie istniejące duchowe cechy pojawiły się $\mathrm{w}$ biegu naturalnej historii i w embriologicznym rozwoju człowieka, skoro nie istniały przed miliardami lat w systemie słonecznym. Natomiast jeżeli się przyjmie, że wszystko to, co jest materialne, posiada protopsychiczną naturę, to wtedy staje się zrozumiałym rozwój psychicznych własności. Tylko przy założeniu panpsychistycznego identyzmu problem „harmonii z góry ustanowionej” znaj-

\footnotetext{
17 Tamże, 237.

18 Tamże, 240.

19 Tamże, 277-278.

20 Tamże, 244.
} 
duje zadowalające rozwiązanie ${ }^{21}$. Właśnie dlatego, że w sensie panpsychistycznego identyzmu fizykalne własności przedstawiają równocześnie własności protopsychiczne, był możliwy ich rozwój w biegu długiej ewolucji ${ }^{22}$. Konsekwencją tych założeń jest twierdzenie, że procesy psychiczne są tym samym, co odpowiadające im fizjologiczne procesy w mózgu. Prawa psychiczne stają się prawami fizjologicznymi i są tylko określane innymi wyrażeniami, inną nomenklaturą ${ }^{23}$.

Przy takich założeniach nie dziwi wnioskowanie Renscha, że skoro drobiny DNA są zdolne do przekazywania dziedzicznych duchowych cech $\mathrm{z}$ pokolenia na pokolenie, to bliską wydaje się $\mathrm{mu}$ hipoteza, iż drobiny i składające się na nie atomy węgla, wodoru, tlenu i fosforu już posiadają protopsychiczną naturę. Konsekwentnym krokiem jest rozszerzenie tej hipotezy na wszystkie atomy i powstałe $z$ nich drobiny ${ }^{24}$. Dotyczy to także i mózgu, ponieważ substancja mózgowa składa się z takich samych atomów i elementarnych cząstek materii ${ }^{25}$. Wszystko to przybliża nas - zdaniem Renscha - do przekonania, że cała materia posiada protopsychiczną naturę, że ciało i dusza stanowią nierozdzielalną jedność $\mathrm{w}$ sensie psychistycznego identyzmu ${ }^{26}$. Upłynie jednak dużo czasu, zanim rozwiążemy całkowicie problem stosunku duszy do ciała, choć już możemy stwierdzić, że hipoteza identyczności fizjologicznych procesów mózgowych z czynnościami duszy jest poparta przez wiele doświadczalnych danych. Wyjaśnienie tej bezpośredniej odpowiedzialności w sensie identyzmu czyni bardziej prawdopodobną hipotezę protopsychicznej natury materii, która składa się na mózg i występujące w nim wahania potencjałów ${ }^{27}$.

Dla ścisłości trzeba zaznaczyć, że według Renscha nie ma żadnej ,,psychofizycznej materii", a jest tylko szczególne uporządkowanie komórek w mózgu, co stwarza warunki, które są konieczne do powstawania świadomościowych związków, przeżywanych przez idnywidua ${ }^{28}$. Tego rodzaju identyzmu nie należy też rozumieć, że cała materia ma być pomyślana jako posiadająca duszę. Hipotezę identyzmu należy rozumieć w ten sposób, że u podstaw materii leży coś ambiwalentnie neutralnego, dzięki czemu przypisujemy jej protopsychiczną naturę. Według Renscha tylko w ten sposób jest możliwe wyjaśnienie, jak przy skomplikowanych procesach $\mathrm{w}$ naszym centralnym systemie nerwowym mogą powstawać psychiczne zjawiska ${ }^{29}$, przy czym trzeba abstrahować od wszelkich innych możli-

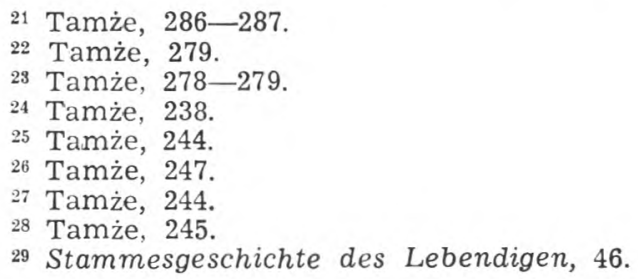


wości, które przekraczają nasze doświadczenia, a więc od transcendentalnych i nieudowodnionych założeń zarówno filozoficznych jak i religijnych. Przez to Rensch nie chce powiedzieć, że nie może być dane coś, co nie jest przez nas ujmowalne czy ujęte. Jednak naukowy obraz świata musi ograniczyć się do doświadczalnych faktów ${ }^{30}$. Rensch sądzi, że podobny pogląd znajdujemy u Piotra Teilharda de Chardin ${ }^{31}$.

\section{Konsekwencje hipotezy identyczności}

Problem wolności woli

Pierwszą konsekwencją hipotezy identyczności jest zaprzeczenie przez Renscha wolności woli zwierzęcej i ludzkiej. Mówimy także „zwierzęcej”, ponieważ Rensch utożsamia psychiczne zdolności małp z ludzkimi. Właśnie dlatego sądzi, że wolności woli nie można uważać za kryterium zasadniczej różnicy między człowiekiem i zwierzęciem, jak to czyni tradycja. Rensch uważa za prawdopodobne, że przebiegi motywacji i wolne działanie są zawarunkowane przyczynowo. Nawet ludzkie myślenie, jak np. rozwiązywanie matematycznego zadania, jest zawarunkowane przez dominujące wyobrażenie „rozwiązania”. Rensch przyznaje jednak, że procesy myślenia są często bardzo skomplikowane i nie da się przedstawić ich jednoznacznie, a więc nie da się udowodnić, że nie posiadamy wolnej woli. Wobec tego możemy to założenie określić tylko jako prawdopodobne ${ }^{32}$.

Prawdopodobieństwo to stara się Rensch uzasadnić w różny sposób. Najpierw powołuje się na zasady teorii ewolucji. Psychiczne zdolności rozwijały się w biegu ewolucji przez coraz większą komplikację mózgowych struktur i w ten sposób doszło $u$ wyższych zwierząt i ludzi do powstania procesów woli. Procesy te charakteryzują się tym, że dominujące wyobrażenie czy przedstawienie powoduje asocjacyjny ich przebieg. Skoro materia i duch są identyczne, to odnosi się to dó wszystkich psychicznych procesów, a więc i do woli. Wobec tego istnieje możliwość, że człowiek nie posiada wolnej woli, gdyż istnieje każdorazowo tylko asocjacyjne następstwo jej czynności. Jest to szczególnie jasne, pisze Rensch, gdy mamy do czynienia tylko z jednym motywem. Przy wielu motywach sprawa komplikuje się i właśnie wtedy powstaje poczucie ,wolnej woli" ${ }^{33}$.

30 Das universale Weltbild, 247-248.

31 Stammesgeschichte des Lebendigen, 46.

32 Das universale Weltbild, 227-228.

${ }^{83}$ Tamże, 291. 
Jako główny argument przeciwko wolnej woli przedstawia Rensch następujący: Cała ewolucja od powstania systemu słonecznego, naszej ziemi, pierwszych istot żywych, aż do wykształcenia się zwierząt i człowieka, stanowiła określony proces, który przebiegał według praw natury. Gdyby przeto nasze dowolne procesy myślenia i woli były wolne, to byłoby to rownoznaczne z przełamaniem praw natury. Gdyby były wolne, to powstałoby pytanie, jak i skąd powstały, skoro ewolucja przebiegała przez miliardy lat zawsze według praw natury. To wzrastający stopień komplikacji procesów mózgowych sprawił, że procesy woli ukazują się nam jako ,wolne”. Nie możemy zatem przypisywać wolnej woli ani zwierzętom ani człowiekowi. Codzienne wyobrażenie laików o posiadaniu wolnej woli jest według Renscha poddawane coraz bardziej w wątpliwość przez niemałą liczbę filozofów. Przykładowo Rensch wymienia Hobbesa, Spinozę, Kanta, Schopenhauera, Voltaire, Ziehena i Plancka. Inny sposób myślenia traktuje Rensch lekceważąco, uważając za zrozumiałe, że wszyscy ludzie, którzy nie posiadają wgłębnej analizy procesów myślenia, są przekonani o wolności woli i to wystarcza im w codziennym życiu. Tego rodzaju mniemanie upada według Renscha podobnie jak przekonanie, że barwy stanowią własność przedmiotów, choć są wywołane przez pobudzenia w oczach i mózgu ${ }^{34}$.

Dla uzasadnienia swego paglądu przytacza Rensch także agrument fizykalny, mianowicie gdyby wola była wolna, to byłoby to równoznaczne z przełamaniem prawa zachowania energii. Wprawdzie ludzie potocznie wierzą, że mogą nadawać swym myślom dowolny kierunek i w ten sposób uzasadniają wolność woli. Według Renscha zmiana kierunków myślenia i działania jest spowodowana przez motywy ${ }^{35}$. Chcąc uzasadnić wolność woli indeterminiści powołują się na mikrofizykę, lecz zdaniem Renscha wolność w dziedzinie mikrofizyki może być i jest podawana w wątpliwość. Nasze dążenie do ,wolności” nie obala poznania, że wszelkie procesy, a więc także asocjacyjne przebiegi procesów nerwowych w naszym mózgu, są ostatecznie zawarunkowane przez prawa na$\operatorname{tury}^{36}$.

Z tak pojętej,,wolności woli" płyną ważkie konsekwencje dla oceny moralności czynów ludzkich, dla prawa karnego, psychiatrii i psychologii. Dyskusje przedstawicieli tych nauk nad odpowiedzialnością za czyny nie doprowadziły do jednolitego stanowiska w tej sprawie. Według Renscha nie mogło to się stać dlatego, że nie jest możliwy przekonywający dowód pełnej determinacji ludzkiego myślenia, a osądy w tej sprawie zależą także od stopnia biologicznej i teoriopoznawczej wiedzy oraz od religij-

\footnotetext{
84 Tamże, 293.

35 Tamże, 291; Basale Prinzipien, 55.

36 Das universale Weltbild, 293.
} 
nych przekonań. Gdyby jednak zaprzeczenie wolności woli było uzasadnio_ ne, reasumuje Rensch, to każdy czyn a w konsekwencji i każde przestępstwo, byłoby uznawane za zdeterminowane przez dziedziczne założenia, wychowanie, środowisko, środki masowego przekazu, psychiczne depresje i afekty. W takim przypadku byłoby trudno, względnie byłoby zaledwie możliwym podnoszenie zarzutu „winy” ${ }^{87}$.

Problem etyki i religii

Etykę pojmuje Rensch jako naukę o normach moralnego myślenia i działania oraz jako naukę o wartościach. Dla zrozumienia etycznego zachowania się Rensch przypisuje wielkie znaczenie dziedzicznemu podłożu instynktów. Człowiek jest bowiem zwierzęciem społecznym, podobnie jak wilki, pawiany, zebry, antylopy i inne zwierzęta, które posiadają wrodzony pęd do łączenia się w stada. Przez życie w społeczeństwie powstawały zarówno u zwierząt jak i u ludzi indywidualne znajomości, częściowe przyjaźnie. U zwierząt dochodzi do walk przede wszystkim o pożywienie, partnera płciowego i zajęcie stanowiska w stadzie. Walki te zostały zrytualizowane i utrwalone przez dziedzictw.o. Gesty poddania się czy pokory u przeciwników, hamowały większe uszkodzenia ciała i prowadziły do zaprzestania agresji i walki. W ten sposób wytwarzały się korzystne dla ogółu dziedziczne sposoby zachowania się.

W linii rozwojowej prowadzącej do dzisiejszego człowieka pozostały do pewnego stopnia te instynktowe założenia, co jest najbardziej widoczne przy sterowanym hormonami macierzyńskim zachowaniu się matki i stosunku obu płci do dziecka. Podobnie pozostały zachowane chęć imponowania przy tworzeniu się par i gotowość poddania się kobiety. Wszystkie tego rodzaju zachowania mogą zdaniem Renscha uchodzić za aprioryczne elementy naszego moralnego postępowania. Wraz z mową, uczeniem się przez doświadczenie i możliwością przekazywania przez tradycję korzystnego zachowania się, doszło do utrwalenia się także niedziedzicznego zachowania. We wzrastający sposób mogły rozwijać się normy „moralności" i prawo, które przykryły częściowo ich instynktowne podłoże. W każdym razie, pisze Rensch, gdy mówimy o moralności nie mogą być pominięte te dziedziczne aprioryczne podstawy ${ }^{38}$.

Przechodząc do omawiania religii Rensch pisze, że wszystkie wielkie religie chcą dać mocną i pewną podstawę ludzkiemu myśleniu i działaniu. Właśnie dlatego religie mogą istnieć przez dalsze jeszcze stulecia. Początki religii są stare, a uprzednie założenie dla jej powstania, jak

37 Tamże, 294.

38 Tamże, 174-176. 
zresztą i dla powstania etycznych wyobrażeń, stanowiła mowa, która prawdopodobnie zaczęła się rozwijać, gdy powstał Homo erectus ${ }^{89}$. Według Renscha obecny stan filozoficznej i przyrodniczej wiedzy nie da się pogodzić z religijnymi przekonaniami. Przykładem jest wędrówka dusz przyjmowana przez hinduizm i buddyzm, która jest sprzeczna z naszą wiedzą o zależności duchowych zjawisk od struktury ludzkiego mózgu oraz wiedzą o dziedziczności dodatnich i ujemnych cech. Wierzące społeczności pozostaną jednak nadal, ponieważ wielu ludzi pragnie utrzymać obraz wyższej istoty, która stworzyła świat, prowadzi i kieruje życiem do której można się zwracać w potrzebie. Religijne uczucia są podtrzymywane i intensyfikowane przez ryty, religijną muzykę i modlitwy kapłanów. Nie można też zaprzeczyć, że u wielu narodów etyczne postępowanie jest w znacznym stopniu określane przez religię. Zdaniem Renscha jest to szczególnie widoczne w krajach o ściśle religijnym wychowaniu, jak np. w islamie i u Mormonów. Rensch uważa, że jednak jest możliwe uporządkowane moralne życie społeczne bez religijnego podłoża, jak tego dowodzą komunistyczne kraje ${ }^{40}$.

Pomimo krytyki religii Rensch jest przekonany, że przedstawiony przez niego ewolucyjny i zgodny z hipotezą identyczności obraz świata nie stoi w całkowitym przeciwieństwie do religii. Oczywiście, pisze, pojęcie osobowego Boga jako wyposażonego w ludzkie cechy jest niemożliwe do pogodzenia z naszą wiedzą. Jeżeli jednak religia będzie występowała jako chrześcijański czy teozoficzny panteizm, w konsekwencji którego istnienie Boga jest zakładane uprzednio w każdym zdarzeniu, to zbieżność z ewolucyjnym obrazem świata jest widoczna. Takie panteistyczne ujęcie Boga dzieli od ewolucyjnego obrazu świata tylko słowo. Wystarczy zastąpić rządzące światem prawa przez pojęcie Boga, ponieważ tak jak Bóg, tak irracjonalna prawidłowość świata jest „,niestworzona”, ,samostwarzająca się" i ,wszechmocna”. Związki te stają się jeszcze bardziej ścisłe ze względu na protopsychiczną naturę materii. Wiedza o naszym koniecznym poddaniu się uniwersalnej prawidłowości wszelkich zdarzeń może wzbudzić w nas uczucie wielkości i bezpieczeństwa naszego istnienia w podobny sposób jak religijna wiara ${ }^{41}$.

W artykule z 1980 r. Rensch jeszcze bardziej tonuje swe stanowisko wobec religii. Mianowicie pisze, że psychofizyczny identyzm jest całkowicie możliwy do pogodzenia z religijnymi poglądami. Jeżeli bowiem, zgodnie z teologicznym ujęciem, cała ewolucja aż do człowieka włącznie jest uważana za proces określony przez Boga, to można w to włączyć także filoi ontogenetyczną psychogenezę. Odpadłaby wtedy trudność włączenia każ-

39 Tamże, 174.

40 Tamże, 298-299.

${ }^{41}$ Tamże, 299. 
dorazowo duszy do zarodka. Łatwiej też byłoby wtedy zrozumieć odpowiedniość procesów mózgowych i psychicznych w sensie „ustawionej z góry harmonii" Leibniza. Obecnie przybiera na sile redukcja prawie wszystkich procesów biologicznych do molekularnych, atomowych i podatomowych procesów, a tych do ostatecznych uniwersalnych praw, jak przyczynowość, szybkość światła, elementarne ładunki, prawa zachowania i stałe, np. Plancka. Z tego wynika, że są ,ostateczne dane”, że istnieje coś niesprowadzalnego do czegoś innego, że istnieje coś irracjonalnego. Ostatecznie nie ma różnicy, pisze Rensch, czy mówimy o działalności tych praw, czy o działaniu Boga ${ }^{42}$.

\section{Problem ostatecznego sensu istnienia i ludzkiego działania}

Każda nasza czynność, czy to dotycząca spraw codziennego życia, czy też społecznych, politycznych i kulturowych zagadnień, zakłada jakiś sens działania, a to naprowadza nas na problem sensu naszego istnienia i istnienia świata. Rensch uważa, że Homo erectus, Homo neandertalensis i podobnie także wczesny Homo sapiens prawdopodobnie nie posiadali pojęcia sensu, pdobnie jak nie istnieje ono dla innych istot żywych. „Sens” pierwszych ludzi polegał na zdobywaniu pożywienia, zaspokajaniu życiowych potrzeb i przekazywaniu życia. Dopiero ludziom na wyższych stopniach kultury wydawało się nieznośnym wyobrażenie, że u spodu wszelkich procesów nie leży , ostateczny sens”. Dlatego powstające wraz z rozwojem kultury wyższe religie sformułowały przedstawienie celu, do którego winni dążyć ludzie. Ten „sens” stanowi szczęśliwe życie „w niebie”, czy też dojście do nirwany przez zdobywanie doskonałości w wędrówce dusz. We wszystkich tych oczekiwaniach chodzi według Renscha o religijne wyobrażenia, które nie posiadają uzasadnienia w naukowym poznaniu.

Zgodnie z ewolucyjnym obrazem świata kosmos wykształcił się na podstawie działania praw natury i ten rozwój będzie biegł niewyobrażalnie długo dalej aż do końca wszechświata, a więc także ludzkości i naszej planety ziemi. Dlatego według Renscha nie może być mowy o „ostatecznym sensie" rozwoju naszej planety i ludzkości. Natomiast możemy dążyć do ograniczonych sensów przez zakładanie celów we wszystkich naszych praktycznych i teoretycznych kulturowych dążeniach. Spontanicznie nasuwa się pytanie, czy wobec tego pozostał nam tylko fatalizm? Rensch stanowczo zaprzecza temu, gdyż znaczyłoby to przyjąc bierną postawe $\mathrm{w}$ życiu (Hände in den Schoss legen). Posiadamy wrodzoną dążność do aktywności i tworzenia, choć jest ono zawarunkowane prawami natury.

42 Stammesgeschichte des Lebendigen, 46-47. 
Nasz umysł tak wykształcił się w biegu ewolucji, że zawsze wykazuje aktywność. Mamy wrodzony pęd do zachowania życia, mnożenia się, zdobywania stanowiska w społeczeństwie. Jesteśmy tak wyposażeni, że odczuwamy radość z wyników pracy, z osiąganych celów, z poprawy warunków życia, z pełnienia dobrych czynów. Spontanicznie włączamy się w ponadosobowe wychowawcze czy polityczne struktury. Nasza ludzka natura nie pozwala nam na bierne zachowanie ${ }^{43}$.

Przykłady takiego aktywnego zachowania się daje nam historia. Grecy wierzyli w Mojry - uosobienie losu, którym nawet bogowie byli poddani, lecz to nie przeszkodziło im $\mathrm{w}$ tworzeniu wiedzy i sztuki, $w$ obronie państwa i zasiedlaniu obszarów Morza Sródziemnego. Podobnie wiara w kismet-przeznaczenie nie przeszkodziła Arabom w stworzeniu matematyki, astronomii, filozofii, medycyny i wspaniałego budownictwa. Podobnie wiara $\mathrm{w}$ predestynację nie przeszkodziła chrześcijanom $\mathrm{w}$ tworzeniu wielkich dzieł. Także obecna wiara $\mathrm{w}$ zawarunkowania naszego myślenia i działania nie przeszkadza w planowaniu kulturalnego rozwoju ludzkości. Fatalistyczny sposób myślenia mógłby szkodzić jedynie w powiązaniu z koniecznością śmierci. To jednak nie zachodzi, pisze Rensch, ponieważ nie ma ,ostatecznego sensu i celu" naszego istnienia, gdyż nasza planeta i ludzkość są włączone w stawanie się i przemijanie wszystkich ciał $\mathrm{w}$ kosmosie ${ }^{44}$.

\section{Uwagi krytyczne}

Zgodnie z hipotezą identyczności duch jest funkcją mózgu, która występuje na określonym stopniu organizacji centralnego systemu nerwowego. Stany psychiczne, duchowe i świadomościowe są identyczne ze stanami zespołów komórek nerworwych w mózgu. Jeżeli taka identyczność istnieje, to powinna być zachowana logiczna zasada identyczności. Zasada ta głosi, że każda rzecz jest identyczna ze sobą. Gdybyśmy twierdzili, że dwie rzeczy są identyczne ze sobą, to sprzeciwialibyśmy się tej zasadzie, gdyż dwie rzeczy nigdy nie mogą być jedną rzeczą. Jeżeli tak jest, pisze A. Menne, to byłoby logicznym wybrykiem mówić o dwóch rzeczach i twierdzić, że są jedną rzeczą. Natomiast można łączyć dwie nazwy z jedną rzeczą, gdyż wtedy sprzeczność jest tylko pozorna. Logicznie poprawnie można więc powiedzieć, że identyczność zachodzi wtedy, gdy dwie nazwy $n$ i $m$ oznaczają to samo indywiduum $a^{45}$.

W zastosowaniu do hipotezy identyczności logiczna zasada mówi, że jest tylko jedna substancja, jedno indywiduum, natomiast są dwie nazwy:

48 Das universale Weltbild, 296-297.

44 Tamże, 297.

45 A. Menne, Einführung in die Methodologie, Darmstadt 1984, 66. 34 - Analecta Cracoviensia 
zjawiska fizyczne i zjawiska duchowe. Tak też głosi Rensch. Czy jednak jest to słuszne w zastosowaniu do człowieka? G. Schischkoff zwraca uwage na to, że nasza świadomość nie jest nigdy identyczna ze sobą, gdyż jest stanem, kontynuacją i rozwojem naszego $\mathrm{Ja}^{46}$. Tu powstaje problem dla hipotezy identyczności Renscha. Posiadamy jedno Ja, w którym zmienność psychiczna nie jest identyczna ze zmiennością procesów nerwowych w mózgu. Innym prawom podlega zmienność procesów nerwowych, a innym zmienność stanów świadomości. Nie istnieje współbieżność pobudzeń komórek nerwowych w mózgu ze świadomym odbiorem podniet. Nasza świadomość nie przyjmuje całej podaży informacji, lecz wybiera je zgodnie $z$ potrzebami, zainteresowaniami i uwagą, modyfikuje je, inicjuje i przywołuje z pamięci. Tak więc nasze świadome przeżycia nie są prostym lustrzanym odbiciem czynności mózgu. Gdyby tak było, piszą Eccles i Robinson, to nasze świadome Ja byłoby tylko biernym widzem neuronalnej maszynerii przeprowadzanych przez mózg czynności ${ }^{47}$. Bezpośrednie doświadczenie, które Rensch uznaje za pierwotne i rzeczywiste dane mówi nam, że posiadamy jedno Ja, obejmujące dwie jakby warstwy, które rozwijają się częściowo razem, a częściowo osobno. Trudno więc mówić o zupełnej identyczności nerwowych i psychicznych procesów.

Rensch wyklucza ze swych rozważań Ja, powołując się na mające występować rozdwojenie Ja przez rozdzielenie półkul mózgowych od siebie. Jednakże nie jest to tak jasne, jak sądzi Rensch. Doświadczenia wykazują bowiem, że przecięcie spoiwa wielkiego nie musi prowadzić do rozdwojenia osobowości, która zdaje się być związana z dominującą półkulą móz$\mathrm{gu}^{48}$. F. Wuketis twierdzi, że świadomość jest produktem realnej historii rozwoju i oddzielanie świadomości od mózgu jest absurdem ${ }^{49}$. Owszem, lecz ten absurd popełnia natura, gdy wyłącza świadomość przy zachowanej normalnej pracy mózgu. Właśnie na to zwraca uwagę Eccles. Według niego wyniki badań nad ludzkim mózgiem nie dają całkowitego wyjaśnienia ludzkiego zachowania, a przede wszystkim nie potrafią odpowiedzieć na zasadnicze pytanie, czym jest ludzkie Ja. Świadomego ludzkiego Ja nie można utożsamiać z czynnością nerwów, ponieważ brak świadomości zachodzi także przy pełnej działalności neuronalnego mechanizmu. Nasza osobowość, jedność i wszystkie aspekty naszych doświadczeń zależą wprawdzie od mózgu, lecz nie zależą całkowicie od genetycznej informacji, która zbudowała mózg. Nie wiemy, jak doszliśmy do bycia sobą, które jest zakotwiczone w naszym mózgu. Na przestrzeni całego

${ }^{46}$ G. Schischkoff, Philosopisches Wörterbuch 21, Stuttgart 1982, 303.

47 J. C. Eccles, D. N. Robinson, Das Wunder des Menschseins - Gehirn und Geist, München/Zürich 1985, 57, 64-65.

48 Tamże, 68-69.

49 Dz. cyt. 242. 
życia nasze Ja zachowuje ciągłość, pomimo braku łączności z mózgiem w śpiączce, narkozie i innych stanach nieświadomości. To daje zdaniem Ecclesa podstawę do twierdzenia, że Ja posiada autonomiczną egzystencję, która przekracza luki w świadomości ${ }^{50}$.

Rensch, którego hipoteza identyczności należy do umiarkowanego materializmu, stale powołuje się na poznanie naukowe, jako na jedyne obiektywne kryterium rzeczywistości. Przypisuje wyjątkową rolę przyrodniczym argumentom właśnie w tej dziedzinie, w której nie posiadają przekonywającej mocy. Takie jest zresztą zdanie wielu autorów zarówno spośród filozofów jak i przyrodników. Według A. Görresa wszystkie przyrodnicze metody uprzedmiotawiają, obiektywizują, tymczasem to, co jest duchowe w człowieku, leży w sferze nieprzedmiotowego. Badanie tej sfery nie jest zadaniem przyrodniczej nauki i nie leży w zakresie jej możliwości, lecz jest sprawą filozoficznego, względnie teologicznego instrumentarium. Kto odrzuca to instrumentarium, ten nie wejdzie $\mathrm{w}$ sferę duchowego. Stosując przyrodnicze metody do sfery ducha, czyni się metodę fetyszem i czyni się z metod ideologię ${ }^{51}$.

H. Sachse słusznie zauważa, że często czyni się próby uzasadniania humanistycznych treści przyrodniczo, ażeby wzmocnić siłę argumentacji. Jednak przez takie postępowanie łudzimy się tylko fałszywą pewnością. We wszystkich teoriach dotyczących stosunku ducha do ciała chodzi tylko o ogólne interpretacje, które nie posiadają pokrycia w nauce. Znaczy to, że nie można ich wyprowadzić z przyrodniczych obserwacji, a równocześnie nie można przyrodniczo nic powiedzieć przeciwko nim. Jest rzeczą naturalną, że każda teoria posiada swoje uzasadnienie, jednakże ma ono różny ciężar dla różnych dziedzin i różną moc przekonującą ${ }^{52}$.

Inni przyrodnicy wypowiadają jeszcze bardziej ostry sąd o naukowym poznaniu $w$ ogóle. I tak $R$. U. Sexl pisze, że nawet $w$ dziedzinie fizyki wymyślamy hipotezy, które, jak każda ludzka wiedza, są niepewne i domagają się ciągłej rewizji. Z samych obserwacji i eksperymentów fizyki nie da się wyprowadzić pewnych wniosków o strukturach, które leżą u podstaw naszego świata. Przyrodnicze teorie nie są ani prawdziwe, ani ostateczne, ani pewne. Stanowią tymczasowe hipotezy, które człowiek rozwija w jego pogoni za rzeczywistością i zrozumieniem naszego świata. Prawda i pewność to tęsknota ludzkości, która musi pozostać niezaspokojoną ${ }^{53}$. Możemy się spierać o pełną czy niepełną słuszność myśli Sexla,

50 J. C. Eccles, Das Gehirn des Menschen, München/Zürich 1979, 223-224; Tenże, Wahrheit und Wirklichkeit, Berlin/Heidelber/New York 1975, 8.

51 A. Görres, Kennt die Psychologie den Menschen?, [w:] Unser Wissen vom Menschen, Düsseldorf 1977, 38.

${ }^{52} \mathrm{H}$. S a chs e, Wie entsteht der Geist?, [w:] Wie entsteht der Geist? Karlsruhe 1980,92 .

${ }_{53}$ R. U. S ex1, Was die Welt zusammenhält, Physik auf der Suche nach dem Bauplan der Natur ${ }^{3}$, Stuttgart 1983, 242. 
jednak to jest pewne, że przy pomocy przyrodniczego poznania nie możemy argumentować na rzecz duchowych zjawisk i ich natury oraz ich identyczności czy nieidentyczności z nerwowymi procesami w mózgu.

Vollmer słusznie zauważa, że Rensch wprowadza nieobserwowalne parametry, gdy przypisuje elementarnym cząstkom materii własności, których w żaden sposób nie można stwierdzić naukowo. Każda próba takiego uzasadnienia jest $\mathrm{z}$ góry wykluczona. Rensch twierdzi, że sprawdzalność jest jednym z kryteriów, według których współczesne przyrodoznawstwo ocenia naukowość teorii. Wobec tego teza o protopsychicznych własnościach materii nie należy do zakresu nauk doświadczalnych. Nadto, gdyby elementarne cząstki posiadały protopsychiczne własności, to musiałyby posiadać także protobiontyczne własności, a więc protoprzemianę materii, protorozmnażanie się, protomutację, protoświadomości, a wraz z nią protoból, protowierność i in. Ta karykatura, pisze Vollmer, wykazuje jasno, jak sztuczna i bezużyteczna jest hipoteza Renscha o protopsychicznych własnościach materii. Według Vollmera te uwagi nie muszą stanowić zarzutu, ponieważ metafizyczne rozważania o hipotezie identyczności, mogą posiadać swą wartość, trzeba jednak to wyraźnie powiedzieć ${ }^{54}$.

Różni materialiści, piszą Eccles i Robinson, kładą wielki nacisk na to, że ich teoria duszy i ciała jest zgodna z prawami natury i najnowszym stanem wiedzy. Jednakże $w$ prawach fizyki, chemii czy biologii nie znajdziemy nigdzie wskaźnika mówiącego o duchu czy świadomości. Przez to nie twierdzi się, że świadomość nie wyłoniła się w procesie ewolucji. Natomiast twierdzi się to, że prawa natury nie wykazują tego. Wiara panpsychistów, że rodzaj początkowej świadomości tkwi w całej naturze, przypuszczalnie już w atomach i elementarnych cząstkach materii, nie jest niczym uzasadniona przez fizykę. Według tych autorów wszystkie teorie panpsychistów, epifenomenalistów czy identystów kolidują także z teorią ewolucji, gdyż wszystkie zaprzeczają przyczynowej działalności świadomości. Przez to staje się dla nich niemożliwym wyjaśnienie ewolucyjnej ekspansji świadomości, co jest niezaprzeczalnym faktem ${ }^{55}$.

Badanie procesów nerwowych $\mathrm{w}$ mózgu nie jest równoznaczne $\mathrm{z}$ badaniem duchowej strony człowieka. Rensch powołuje się na rzekomo zachodzące u zwierząt myślenie, akty woli, badawczą ciekawość itp. Tymczasem badania wykazują coś wprost przeciwnego. Wskazują na istniejące psychiczne bariery, których zwierzęta nie mogą przekroczyć. Rensch nie rozróżnia między poznaniem zmysłowym i umysłowym. Psychizm zwierzęcy jest zawsze skierowany ku konkretnym biologicznym celom i potrzebom. Zachodząca u zwierząt ciekawość nie stanowi, jak chce Rensch, przejścia

${ }^{54} \mathrm{~V}$ o $11 \mathrm{mer}$, art. cyt. 24.

${ }_{55}$ Eccles, Robinson, Das Wunder des Menschseins, 62. 
do duchowej pracy. Ciekawość zwierząt nie doprowadziła do przekształcania środowiska ani do rozwijania naukowego życia. Między ciekawością zwierząt i ludzi leży więc, jak pisze P. Lüth, różnica nie stopnia, lecz jakościowa ${ }^{56}$.

Człowiek jest ze swej istoty czymś więcej, gdyż cechuje go transcendencja, ciągłe przekraczanie wszelkich barier. Cecha ta wskazuje na inną zasadę życia u człowieka i tę zasadę nazywamy duszą, względnie duchową stroną w człowieku. Utożsamienie psychizmu zwierzęcego z ludzkim prowadzi do pomieszania niezgodnych rzeczy ze sobą ${ }^{57}$. Biologiczny rozwój mózgu jest poddany prawom natury, natomiast rozwój duchowej strony jest poddany prawom logiki, prawom twórczości. Procesy nerwowe nie mogą być sprzeczne w sobie, natomiast treści duchowe, które napełniają te procesy, rozwijają się często przez przeciwieństwa i sprzeczności poglądów, mniemań, przypuszczeń, hipotez i teorii. Gdyby strona psychiczna była identyczna ze stroną neuronalną, to chyba nie byłoby tyle hipotez o stosunku duszy do ciała. Mieszanie zjawisk biologicznych z duchowymi stanowi nieuzasadniony redukcjonizm, który zresztą jest z góry postulowany przez Renscha. K. Lorenz słusznie pisze, że redukcjonistyczny sposób myślenia trzyma się fikcji ciągłości ewolucyjnych procesów i wierzy mocno, że ten może wytwarzać tylko różnice stopnia. Jak wiemy, każdy krok ewolucji stwarza istotową różnicę. Duchowe życie człowieka jest nowym rodzajem życia ${ }^{58}$.

Rensch stawia więc bez dowodu twierdzenie, że psychizm duchowy jest tylko dalszym stadium rozwoju psychizmu zwierząt. Gdyby psychizm ludzki był tylko dalszym ciągiem rozwoju psychizmu małp człekokształtnych, to właściwie nie mielibyśmy nowego gatunku człowieka, a tylko nowy gatunek małp człekokształtnych. Eccles i Robinson piszą, że jeżeli pseudodarwinista uważa człowieka za szczególnie mądrą małpę, to zgodnie $z$ tą logiką musiałby. uważać ptaka za szczególnie ruchliwą rybę. Jest przecież prostym faktem, że każdy gatunek stanowi coś specyficznego $i$ swoistego ${ }^{59}$. Ewolucja polega $w$ swej istocie nie tylko na rozwijaniu tego, co było już dane, lecz także na tworzeniu czegoś nowego. Jest rzeczą oczywistą, że stronę zmysłową dzielimy ze zwierzętami, lecz jest także rzeczą oczywistą, że nie dzielimy z nimi strony kulturowej, a więc nauki, etyki, sztuki i religii. Gdyby sama funkcja mózgu i wzory neuronalnych połączeń były zdolne do wytwarzania kulturowych treści, czyli duchowego życia, to małpy człekokształtne winny były wejść wcześniej w stadium ewolucji ludzkiej, gdyż posiadają o wiele dłuższy staż swego istnienia.

${ }_{56}$ P. Lüth, Der Mensch ist kein Zufall, Frankfurt a. Main 1984, 247.

57 Ks. T. W o j c i e chowski, Wybrane zagadnienia $z$ filozoficznej antropologii, Kraków 1985, 86 nn.

${ }_{58}$ K. Lorenz, Die Rückseite des Spiegels, München 1977, 212, 217.

${ }^{59} \mathrm{Eccles}, \mathrm{R}$ obins on, Das Wunder des Menschseins, 190. 
W swej argumentacji przeciw wolności woli ludzkiej Rensch znów powołuje się na naukę o mózgu, choć sam przyznaje, że pozostało jeszcze dużo do wyjaśnienia $\mathrm{w}$ tej dziedzinie. Lecz wyniki badań nad mózgiem nie są interpretowane jednoznacznie przez neurologów. Eccles i Robinson, opierając się o nowe dane, interpretują je na korzyść wolnej woli. W. Penfield odkrył, że pierwsze reakcje mózgu, wyzwolone przez zamiar ruchu, mają miejsce nie w korze ruchowej, lecz w komórkach nerwowych tzw. uzupełniającego motorycznego pola (supplementäres motorisches Feld$-S M A)$. Stymulacja tego pola wywołuje nie bardzo lokalizowalne reakcje, które są przekazywane do motorycznej kory. Długo to odkrycie Penfielda było niezauważane. Dopiero doświadczenia R. Porte i C. Brinkmana wykazały, że przy dowolnych czynnościach u małp wiele komórek nerwowych SMA wykazywały impulsy przed impulsami w motorycznej korze. Jeszcze bardziej interesujące doświadczenia przeprowadzili N. Larsen, Per Roland i współpracownicy w Kopenhadze. Pacjent wykonywał zadania motorycznego testu czynnie, a następnie tylko myślowo. Ten wariant eksperymentu nazwano ,wewnętrznym programowaniem”. Elektromyograf nie wykazywał przy tym żadnej aktywności motorycznej kory, natomiast SMA obu półkul były silnie aktywne. Podobne wyniki uzyskał $\mathrm{H}$. Kornhuber w sześćdziesiątych latach. Wynikało z nich, że prawie jedną sekundę przed wykonaniem dowolnego ruchu, jak np. zakrzywienie palca, mózg badanego wykazywał stopniowy wzrost negatywnego elektrycznego potencjału w mózgu. Nazwano to ,potencjałem gotowości” ${ }^{{ }^{0}}$. Oczywiście, nie można $\mathrm{z}$ tych doświadczeń czynić argumentu ani przeciw hipotezie identyczności, ani dowodu na wolność woli. Natomiast wskazują one, jak neutralne są wyniki badań nad mózgiem względem duchowej sfery człowieka.

Wolność woli uzasadnia się filozoficznie, względnie psychologicznie z analizy psychicznych przeżyć, ze świadomości wolności wyboru alternatyw, zdolności działania lub niedziałania oraz działania dobrze lub źle. Rensch zakłada zmuszający wpływ motywów, lecz omija pytanie, skąd się wzięły motywy, jak powstały w mózgu i jak wytworzyły się te determinacje. Jeżeli nie ma wolnej woli, to jak wytłumaczyć zmianę działania na przeciwne lub wprost sprzeczne? Jak wytłumaczyć tak różnorodną twórczość człowieka? Czy jest ona wytworem determinacji mózgowych, czy jakiejś tajemniczej siły na poziomie neuronalnych procesów? Odpowiedzi na te pytania nie znajdziemy w neurofizjologicznych procesach mózgu. Natomiast odpowiedź na płaszczyźnie filozoficznej narzuca się sama: Człowiek jest wolny dzięki zdolności transcendencji, przez którą łamie i przekracza wszelkie bariery. Transcendencja stanowi istotę czło-

${ }^{60}$ Tamże, 201-208. 
wieka i dlatego wolność jest istotną jego własnością. Z tego punktu widzenia wolną jest nie tyle wola, ile osoba, która zapoczątkowywuje i nadaje kierunek świadomym ludzkim działaniom.

Podobne zastrzeżenia nasuwają się w związku z pojmowaniem przez Renscha etyki, religii oraz ostatecznego sensu istnienia świata i człowieka. Pojęcie wartości jest czymś specyficznie ludzkim i podobnie specyficznie ludzkimi są kategorie dobra i zła. Rensch utożsamia etyczne wartości z neurofizjologicznymi procesami w mózgu. Tymczasem, jak pisze Wuketis, trzeba rozróżnić między wypowiedziami o ewolucyjnych założeniach człowieka, a jego ludzkimi potrzebami, które wyrosły dopiero na poziomie refleksyjnej świadomości. Kategorie dobra czy zła nie są określane tylko popędowobiologicznymi komponentami, lecz przede wszystkim są określane kulturowym kontekstem, który posiada własną historię i nie jest redukowalny do bio-ewolucji ${ }^{61}$.

Religijne wyobrażenia zdaniem Renscha nie mogą być poparte poznaniem naukowym, owszem są z nim niezgodne. Rensch zapomina, że religia nie należy do dziedziny biologii. Nikt dotychczas nie potrafił wykazać najmniejszych przedstadiów religii u wyższych zwierząt. Zgodnie z zasadami metodologii przy pomocy przyrodniczych argumentów nie można ani udowodnić ani obalić religii. Według K. Lorenza zgubnie oddziałuje błędne przekonanie, że tylko to, co może być przyrodniczo ujęte, należy do naszego pewnego zasobu wiedzy. Prowadzi bowiem jeszcze naukowo nieuświadomioną młodzież do tego, żeby wyrzuciła za burtę niezmierzony skarb wiedzy i mądrości, który jest zawarty w tradycji każdej kultury i w naukach wielkich religii ${ }^{62}$. B. Kanitscheider ujmuje podobnie stosunek poznania fizykalnego do filozoficznego i religijnego. Żadna przyrodnicza teoria, żadna fizykalna kosmologia nie obejmuje całości poznawalnego bytu, gdyż mówią tylko o czasowo i przestrzennie lokalizowalnych materialnych rzeczach. Nauki przyrodnicze są zamknięte w swych ontologicznych, metodologicznych i epistemologicznych ograniczeniach. W stosunku do rozszerzonych ontologicznych wymagań zachowują się całkiem neutralnie, gdyż te są zdobywane przy pomocy innych poznawczych środków i są kontrolowane przez inne instancje. Przyjęcie względnej autonomii obu tych dziedzin, których łączność może i musi być regulowana tylko przeż logiczne mosty, stanowi najprostsze rozwiązanie dla koegzystencji naturalistyczno-immanentnej przyrodniczej dziedziny i metafizyczno-transcendentnej dziedziny religii ${ }^{68}$.

Pomimo swej krytyki religii Rensch widzi możliwość pogodzenia jej z naukowym poznaniem, jednakże pod warunkiem odrzucenia idei oso-

${ }^{61} \mathrm{~F}$. W uketis, Evolution, Erkenntnis, Ethik, Darmstadt 1984, 181-182, 209.

${ }^{62} \mathrm{~K}$. Lorenz, Die acht Todsünde der zivilisierten Menschheit, ${ }^{14}$, München/ /Zürich 1983, 70 .

${ }_{68}$ B. Kanitscheider, Kosmologie, Stuttgart 1984, 458. 
bowego Boga, a przyjęcia nieokreślonego panteizmu. Rensch nie jest odosobniony w takiej koncepcji Boga, gdyż podobne wypowiedzi możemy znaleźć u niektórych współczesnych przyrodników. Np. według E. Jantscha Bóg objawia się nie w osobowej czy podobnej do osoby formie, lecz w ewolucyjnej całościowej dynamice wielowarstwowej rzeczywistości. Bóg nie jest absolutem, lecz rozwija się, jest po prostu ewolucją. Bóg nie jest stworzycielem, lecz jest duchem wszechświata ${ }^{64}$. H. Fritzsch opowiada się za Bogiem Spinozy i Einsteina, jako za Bogiem będącym jednością świata. Intuicyjne ,wczucie się" w tę jedność zasługuje na miano ,,religijności". Nie ma wiecznego Boga, nie ma wiecznego życia. Fritzsch, podobnie jak Rensch, uważa, że nie ma sporu między tak pojętym Bogiem, religijnością i przyrodoznawstwem ${ }^{65}$. Wszelkie tego rodzaju koncepcje są wynikiem nieuzasadnionych zarówno filozoficznie, jak i naukowo refleksji poszczególnych przyrodników nad religią i Bogiem. W rzeczywistości Bóg i religia nie mieszczą się w przyrodniczych kategoriach, gdyż są transcendentne wobec materii. Próby „wtłaczania” Boga w dynamikę świata są echem panteistycznych kierunków i wpływów filozofii Wschodu.

Według Renscha nie można mówić o ,ostatecznym sensie i celu” istnienia człowieka i świata, gdyż to nie jest zgodne z poznaniem naukowym świata jako stawającego się i przemijającego. W tym przypadku przyrodnicy zajmują wprost przeciwne stanowiska. Według Fritzscha nauka nie może dać żadnej odpowiedzi na pytanie o sens świata i człowieka. Pytania te żądają bowiem równocześnie sądu wartościującego, a tego nie może dać nauka ${ }^{66}$. Nie wiadomo, na jakich przesłankach oparł się Rensch twierdząc, że Neandertalczyk nie znał „ostatecznego sensu", choć miał religijne przeżycia. Według J. Schmidta właśnie pojęcie sensu życia wskazuje na religijne wymiary. Absolutny sens jest możliwy i doświadczalny tylko w otwarciu się na całość bytu i transcendencję ${ }^{87}$. Absolutny sens posiada przeto swe źródło w specyficznej dla człowieka otwartości na wszechświat. Podstawą pytania o sens istnienia człowieka i świata jest bezgraniczna zdolność transcendencji ludzkiego ducha, natomiast zrozumienie sensu życia wiąże się $\mathrm{z}$ wiarą $\mathrm{w}$ Boga ${ }^{68}$. Próby podawania $\mathrm{w}$ wątpliwość pojęcia ostatecznego sensu istnienia człowieka i świata w oparciu o przyrodnicze przesłanki są nieuzasadnione, gdyż zachodzi tu brak logicznego wynikania $\mathrm{z}$ przesłanek.

64 E. Jantsch, Selbstorganisation des Universums, München 1982, $412,47$.

${ }^{65} \mathrm{H}$. Fritzsch, Vom Urknallzum Zerfall, München/Zürich 1983, 327-335.

66 Tamże, 299.

${ }_{67} \mathrm{~J}$. S chmidt, Die Sinnfrage und ihr Verhältnis zur Religion, [w.] B. G r o m, J. Schmidt, Auf der Suche nach dem Sinn des Lebens, Freiburg a. Main 1975, 58. ${ }^{68} \mathrm{H}$. Fries, Der Mensch im Mittelpunkt, [w:] Gott Mensch Universum, Graz/Wien/Køln 1974, 22, 28. 
Reasumując można powiedzieć, że Rensch nie uzasadnił i zresztą nie mógł uzasadnić przyrodniczo swej hipotezy identyczności duchowych zjawisk z neurofizjologicznymi procesami w mózgu. W rozważaniu człowieka, a więc i jego duchowej strony, Rensch słusznie wychodzi w swych rozważaniach z teorii ewolucji, gdyż człowiek wyszedł ze świata i przejął całe biologiczne dziedzictwo od swych zwierzęcych przodków. Do tego biologicznego dziedzictwa należy całe zmysłowe życie człowieka. Jednakże człowiek jest nie tylko ostatnim biologicznym ogniwem ewolucji, lecz także istotą transcendencji, która przekroczyła biologiczne bariery i weszła w nowy świat ducha. Próby redukcji człowieka do biologicznego świata prowadzą wbrew oczywistości do zaprzeczenia tego, co jest wyłącznie ludzkim i co nie było nawet $\mathrm{w}$ zalążku złożone w wyposażeniu dziedzicznym po naszych zwierzęcych przodkach ${ }^{69}$. Próby skrajnych i umiarkowanych materialistów sprowadzenia tego świata do nerwowych procesów w mózgu wynikają nie z naukowych przesłanek, lecz z ,życzeniowego myślenia" (Wunschdenken) i dowolnie przyjętych założeń. W tego rodzaju próbach Eccles i Robinson widzą w materializmie przesąd bez racjonalnego podłoża, gdyż im więcej wiemy o mózgu, tym jaśniej rozróżniamy między mózgowymi procesami a duchowymi zjawiskami ${ }^{70}$. Wraz ze zwolennikami teorii identyczności przyjmujemy jedność człowieka i to jest słuszny moment tej teorii, lecz nie możemy przyjąć identyczności biologicznej i duchowej strony w człowieku, gdyż nie pozwala na to filozoficzna i psychologiczna analiza duchowych przeżyć człowieka.

\section{DIE HYPOTHESE DES PANPROTOPSYCHISCHEN IDENTISMUS VON BERNHARD RENSCH}

\section{$\mathrm{Z}$ u s a m m enf a s s u $\mathrm{g}$}

Die Hypothese des Panprotopsychismus von B. Rensch ist - nach der Meinung mancher Autoren - die profundeste und umfassendste, die im 20. Jahrhundert aus der Feder eines Biologen und Naturphilosophen stammt. Als Grundthese hat Rensch die Identität der geistigen Vorgänge und der physiologischen Hirnabläufe angenommen. Rensch setzt voraus, dass die geistigen Merkmale in der lang andauernden Evolution entstanden und mittels der Genen von einer evolutiven Form auf die nächsten übertragen worden sind. Wenn es aber so ist - sagt Rensch - liegt es nahe anzunehmen, dass die Genen und die sie zusammensetzenden Atome schon protopsychischer Natur sind und dass dies auch für alle anderen Atome und die

${ }^{69} \mathrm{Ks} . \mathrm{T}$. Wojciechowski, dz. cyt. $85 \mathrm{nn}$.

${ }^{70} \mathrm{Eccles}, \mathrm{R}$ obinson, Das Wunder des Menschseins, 61. 
daraus zusammengesetzten Moleküle gilt. Rensch zieht aus seiner Identitätshypothese die der traditionellen Philosophie widersprechenden Schlüsse über den freien Willen, die Ethik und Religion und den letzten Sinn der Existenz des Menschen und der Welt.

Die Grundschwäche der Rensches Hypothese liegt darin, dass er die geistigen Vorgänge, welche die materielle Wirklichkeit transzendieren, zu den Hirnprozessen zurückführen will und nur mittels der naturwissenschaftlichen Erkenntnis erklärt. Dem aber gegenüber muss betont werden, dass die aus der naturwissenschaftlichen Erkenntnis gezogenen Schlïsse nur in dem naturwissenschaftlichen Bereich gelten. Der Mensch bildet zwar eine wahre Einheit, eine Person, aber diese schliesst in sich zwei Schichten, von deren die eine biologisch ist, zu der die neurophysiologischen Hirnprozesse angehören, und die zweite geistig, die die ganze Welt der menschlichen Kultur bildet. 